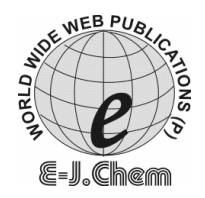

http://www.e-journals.net
ISSN: 0973-4945; CODEN ECJHAO

E-Journal of Chemistry

2009, 6(1), 213-222

\title{
Studies on the Use of Oyster, Snail and Periwinkle Shells as Adsorbents for the Removal of $\mathrm{Pb}^{2+}$ from Aqueous Solution
}

\author{
STEVENS A. ODOEMELAM ${ }^{*}$ and NNABUK OKON EDDY ${ }^{\S}$ \\ *Department of Chemistry, Michael Okpara University of Agriculture, \\ Umudike, P. M. B. 7267, Umuahia, Abia state, Nigeria. \\ ${ }^{\S}$ Department of Chemistry, Ahmadu Bello University, Zaria, Nigeria. \\ saodoemelam@yahoo.com
}

Received 1 April 2008; Accepted 1 June 2008

\begin{abstract}
In view of increasing rate of lead pollution resulting from discharge of lead containing effluents by industries into the environment, this study was carried out to investigate the removal of $\mathrm{Pb}^{2+}$ from aqueous solutions by oyster, snail and periwinkle shells. The effects of contact time and concentration on adsorption, thermodynamics of sorption and distribution coefficients of the adsorbents were examined to optimize the conditions to be utilized for decontamination of effluents containing $\mathrm{Pb}^{2+}$. The study revealed that these materials are good adsorbents that can be used for the removal of $\mathrm{Pb}^{2+}$ from aqueous solution. Adsorption of $\mathrm{Pb}^{2+}$ by oyster, snail and periwinkle shells were found to conform to the classical models of Langmuir, Freundlich and Temkin adsorption isotherms. Thermodynamic consideration revealed that adsorption of $\mathrm{Pb}^{2+}$ by these materials was spontaneous and proceeded via chemical adsorption. The use of these materials for the removal of lead ion from aqueous solution is therefore advocated.
\end{abstract}

Keyword: Lead ions, Adsorption, Pollution, Aqueous effluents, Animal shells.

\section{Introduction}

Lead is one of the most toxic heavy metals known to $\operatorname{man}^{1}$. The risk posed by indiscriminate discharge of lead-containing wastes into the environment is enormous because lead is acutely toxic and can bioaccumulate from one trophic level to the other through the food chain. Thus lead poisoning through ingestion of lead-contaminated food can occur between successive organisms within the ecosystem ${ }^{2-3}$. 
Several methods have been used to remove of heavy metals from industrial effluents. However, one of the best methods is the use of adsorbent. In the light of this, waste biomass has been successfully used for the removal of heavy metals from industrial effluents ${ }^{4-14}$ Results from most of these studies revealed that materials that can significantly remove lead ion from aqueous solution are uncommon. Besides most of these studies are centered on quantitative determination of the amount of heavy metal ion(s) received without reference to the effect of concentration, contact time and adsorption characteristics of the adsorbent. The present study seeks to investigate adsorptive properties of oyster, periwinkle and snail shells for the removal of $\mathrm{Pb}^{2+}$ from aqueous solution.

\section{Experimental}

Samples of periwinkle, oyster and snail shells were respectively dried in the open air. The dried samples were introduced into a furnace whose temperature was successively maintained at 200,300 and $400^{\circ} \mathrm{C}$. The furnace dried samples were ground to powdered form and exposed to free air for four hours (in order to increase it surface area). All reagents used were Analar grade. Double distilled water was used for the preparation of all solutions.

Adsorption study was conducted by adding $100 \mathrm{~mL}$ of different concentrations (0.000302-0.001208 M) of $\mathrm{Pb}\left(\mathrm{NO}_{3}\right)_{2}$ to a column containing $100 \mathrm{~g}$ of each adsorbent. The contact times between the adsorbent and the adsorbate were 10, 20, 30 and $40 \mathrm{~min}$, respectively. After each set of experiment, $10 \mathrm{~mL}$ of the effluent was eluted and preserved for analysis.

Concentration of $\mathrm{Pb}^{2+}$ was determined using Pye Unicam model of atomic absorption spectrophotometer. From the measured concentration of $\mathrm{Pb}^{2+}$, percentage of $\mathrm{Pb}^{2+}$ adsorbed and the amount of sorption per unit mass of adsorbent $(\mathrm{x} / \mathrm{m})$ was calculated using equations 1 and 2 , respectively ${ }^{1-2}$.

$$
\begin{aligned}
\text { \%sorption } & =\left(\mathrm{C}_{\mathrm{i}}-\mathrm{C}\right) / \mathrm{C}_{\mathrm{i}} \times 100 \\
\mathrm{x} / \mathrm{m} & =\left(\mathrm{C}_{\mathrm{i}}-\mathrm{C}\right) / \mathrm{C}_{\mathrm{i}} \times \mathrm{V} / \mathrm{m}
\end{aligned}
$$

where $C_{i}$ and $C$ are initial and final (outlet or effluent) concentrations of $\mathrm{Pb}^{2+}, \mathrm{m}$ is the mass of the adsorbate (in $\mathrm{g}$ ) and $\mathrm{V}\left(\right.$ in $\mathrm{cm}^{3}$ ) is the volume of solution added.

\section{Results and Discussion}

Values of $\%$ sorption of $\mathrm{Pb}^{2+}$ by snail, oyster and periwinkle shells calculated through Equation 1 have been used to plot Figures 1- 3 .

\section{Effect of concentration and contact time}

Figures 1-3 show plots of \% sorption versus contact time for adsorption of different concentrations of $\mathrm{Pb}^{2+}$ by snail, oyster and periwinkle shells, respectively. From the Figures, it can be seen that the amount of $\mathrm{Pb}^{2+}$ adsorbed increased with contact time and decreased with concentration of $\mathrm{Pb}^{2+}$ in the solution. This implies that the rate of adsorption of $\mathrm{Pb}^{2+}$ (given by the slopes of respective lines on the plots) by the adsorbents decreased with concentration. According to Ekop and Eddy ${ }^{15}$, adsorption of metal ions by animal materials depends on the charge of the ion, the surface area of contact, $\mathrm{pH}$ of the solution, duration of contact, the ionic radius of the metal, the organic content of the biomass and the concentration of heavy metals. However, in this study the major factors are duration of contact, organic content and the concentration of $\mathrm{Pb}^{2+}$ ion since other factors were constant. The implication is that the rate of adsorption of $\mathrm{Pb}^{2+}$ by oyster, snail and periwinkle shells should vary with these three factors. At constant contact time and concentration of $\mathrm{Pb}^{2+}$, 
adsorption capacity of snail shell was highest followed by that of oyster while that of periwinkle shell was the least. The observed trend is due to the difference in organic matter content of the respective adsorbents.

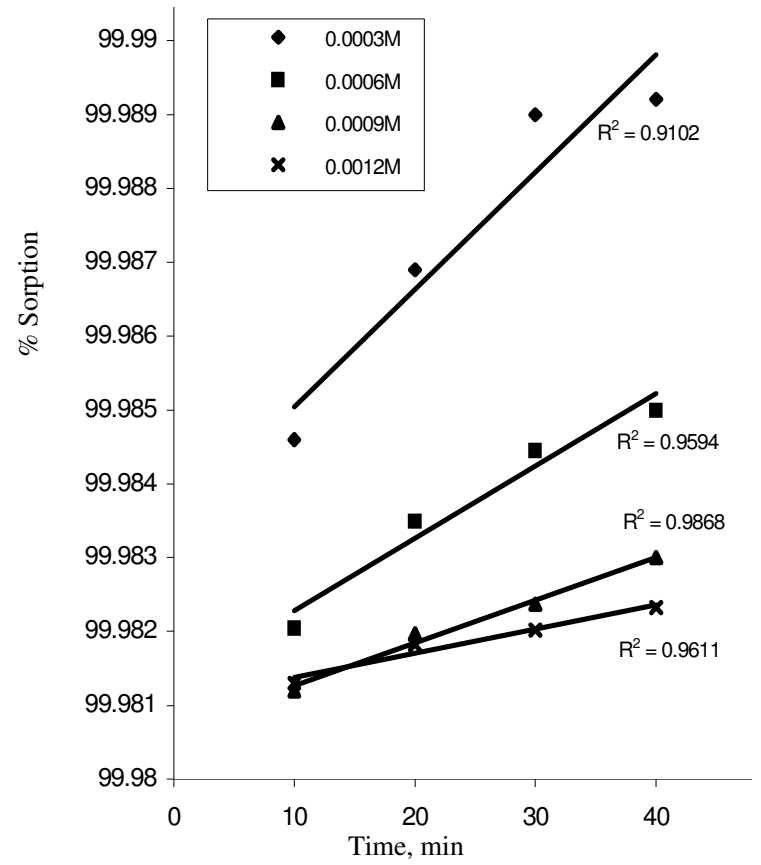

Figure 1. Variation of $\%$ of $\mathrm{Pb}$ adsorbed by snail shell with time.

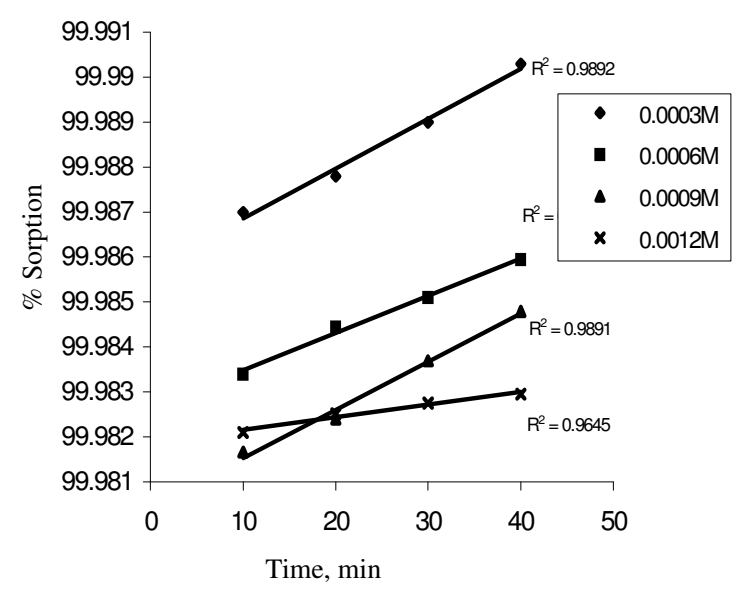

Figure 2. Variation of $\%$ of $\mathrm{Pb}$ ion adsorbed by oyster shell with time.

The effect of concentration of $\mathrm{Pb}^{2+}$ on the percentage of $\mathrm{Pb}^{2+}$ adsorbed was investigated. In all cases, it was seen that $\%$ sorption decreased as the concentration of $\mathrm{Pb}^{2+}$ increased. The decrease may be due to desorption of $\mathrm{Pb}^{2+}$ as its concentration increased ${ }^{16-17}$. It was also observed that above certain concentration, adsorption of $\mathrm{Pb}^{2+}$ tends to stabilize. At this stage, it is expected that the common ion effect must have set in ${ }^{18}$. 


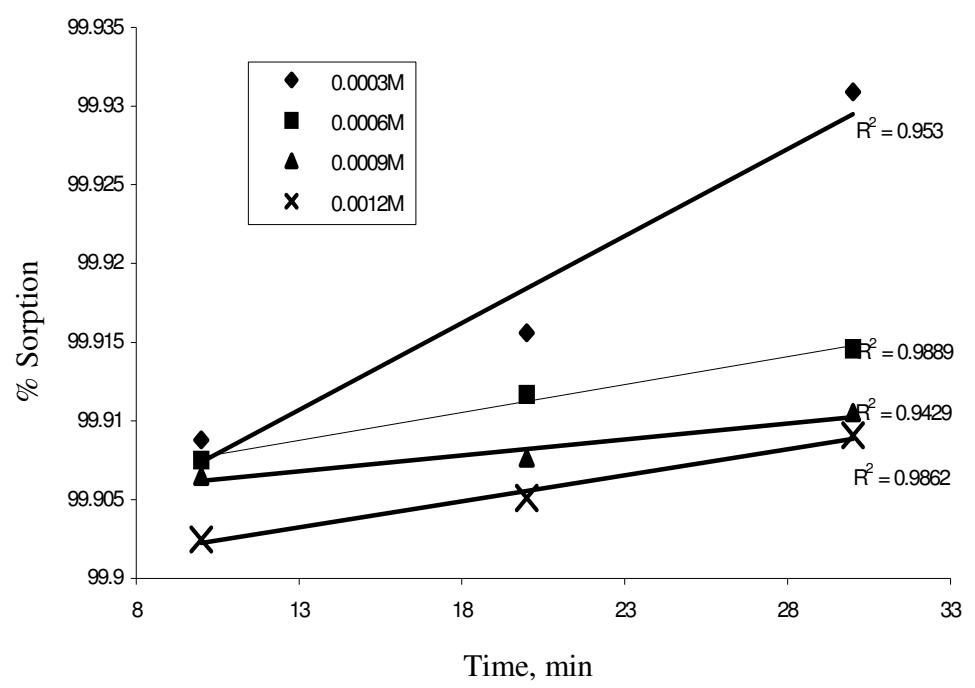

Figure 3. Variation of $\% \mathrm{~Pb}$ ion adsorbed by periwinkle shell with time

\section{Adsorption considerations}

Adsorption isotherm is informative in providing knowledge about the nature and mechanism of adsorption. The most commonly used isotherms are those of Langmuir, Freundlich, Temkin and Florry-Huggins. The general formula for adsorption isotherms is expressed ${ }^{19}$ by Eq 3.

$$
f(0, \mathrm{x}) \exp (-2 \mathrm{a} \theta)=\mathrm{KC}
$$

Where, $f(0, \mathrm{x})$ is configurational factor, $\theta$ is the degree of surface coverage, $\mathrm{C}$ is the concentration of the adsorbate in the bulk solution, $\mathrm{K}$ is the adsorption constant and $\mathrm{a}$ is the interaction parameter.

In order to investigate the adsorption models for the used adsorbents, values of degree of surface coverage and concentrations were used to fit curves for different adsorption models. The results revealed that all the adsorbents obeyed Langmuir and Temkin adsorption isotherms. In addition, adsorption of $\mathrm{Pb}^{2+}$ by oyster shell also obeyed FlorryHuggins adsorption isotherm.

Assumptions of Langmuir adsorption isotherm relates the amount of adsorbate per unit mass of adsorbent to the equilibrium concentration (C) of the adsorbate in solution $\operatorname{according}^{4-5}$ to Eq. 4.

$$
(\mathrm{C} / \mathrm{x} / \mathrm{m})=\left(1 / \mathrm{KV}_{\mathrm{m}}\right)+\left(\mathrm{C} / \mathrm{V}_{\mathrm{m}}\right)
$$

Where, $\mathrm{V}_{\mathrm{m}}$ is the monolayer capacity or surface area of the solid and $\mathrm{K}$ is the binding constant. The implication of Eq. 4 is that a plot of $(\mathrm{C} / \mathrm{x} / \mathrm{m})$ versus $\mathrm{C}$ should give a straight line with slope equal to $1 / \mathrm{V}_{\mathrm{m}}$ and intercept equal to $1 / \mathrm{KV}_{\mathrm{m}}$. Figure 4 shows Langmuir plot for the adsorption of $\mathrm{Pb}^{2+}$ on oyster, snail and periwinkle shells, respectively.

Values of Langmuir parameters $\left(\mathrm{K}\right.$ and $\mathrm{V}_{\mathrm{m}}$ ) calculated through slopes and intercepts of Langmuir plots are recorded in Table 1. From the results, it was found that the surface areas of oyster, snail and periwinkle shells were equal to $0.9998,0.9998$ and 0.9900 , respectively. This indicates that the surface areas of oyster and snail shells were similar while that of periwinkle was slightly lower. This also explains why the adsorption capacities of oyster and snail adsorbents were comparable and higher than that of periwinkle. Values of the binding 
constant $(\mathrm{K})$ for oyster, snail and periwinkle were found to range from $1.1 \times 10^{7}-3.33 \times 10^{7}$, $1.67 \times 10^{7}-3.33 \times 10^{7}$ and $1.28 \times 10^{7}-33.4 \times 10^{7}$, respectively. Although there was no significant difference between values of $\mathrm{K}$ for oyster and snail shells $(\mathrm{P}=0.05)$, the slight differences in values of their respective binding constants explain why values of $\%$ sorption of $\mathrm{Pb}^{2+}$ by snail shell was slightly higher than that of oyster shell. It is also interesting to note that contact time did not affect the monolayer capacity but values of the binding constant varied slightly with time. Thus since $\mathrm{x} / \mathrm{m}$ depends on $\mathrm{K}$ and $\mathrm{V}_{\mathrm{m}}$, it is remarkable to note at this point that period of contact does not significantly affect the adsorption of $\mathrm{Pb}^{2+}$ ion by the adsorbents used. According to Freundlich adsorption isotherm, the fraction of surface coverage $(\mathrm{x} / \mathrm{m})$ is related to equilibrium concentration of the adsorbate according ${ }^{6-7}$ to Eq. 5 .

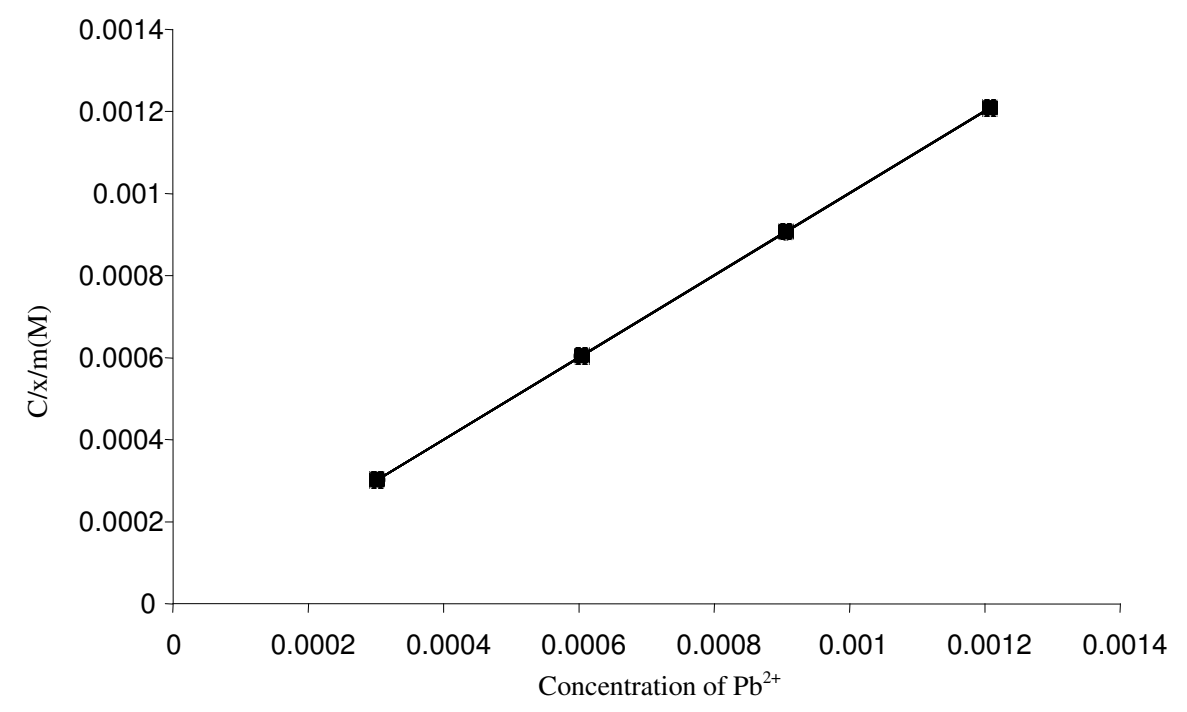

Figure 4. Curve fitting for adsorption of lead ion by snail, oyster(oyst) and pererwinkle (perew) shell according to Lagmuir adsorption isotherm

Table 1. Values of Langmuir parameters for adsorption of $\mathrm{Pb}^{2+}$ on oyster, snail and periwinkle shells.

\begin{tabular}{ccccccc}
\hline \multirow{2}{*}{$\begin{array}{c}\text { Contact } \\
\text { time, min }\end{array}$} & \multicolumn{3}{c}{ Binding constant, K } & \multicolumn{3}{c}{ Monolayer capacity, $\mathrm{V}_{\mathrm{m}}$} \\
\cline { 2 - 7 } & Oyster & Snail & Periwinkle & Oyster & Snail & Periwinkle \\
\hline 10 & $11 \times 10^{7}$ & $1.67 \times 10^{7}$ & $3.37 \times 10^{7}$ & 0.9998 & 0.9998 & 0.9900 \\
20 & $5.0 \times 10^{7}$ & $1.67 \times 10^{7}$ & $33.4 \times 10^{7}$ & 0.9998 & 0.9998 & 0.9900 \\
30 & $1.67 \times 10^{7}$ & $1.67 \times 10^{7}$ & $1.28 \times 10^{7}$ & 0.9998 & 0.9998 & 0.9900 \\
40 & $3.33 \times 10^{7}$ & $3.33 \times 10^{7}$ & - & 0.9998 & 0.9998 & - \\
\hline \multicolumn{6}{c}{$\mathrm{X} / \mathrm{m}=\mathrm{KC}^{1 / \mathrm{n}}$}
\end{tabular}

Taking logarithm on both sides of Eq 5, we get the following Eq. (6)

$$
\log (\mathrm{x} / \mathrm{m})=\log \mathrm{K}+1 / \mathrm{n} \log \mathrm{C}
$$

Where, $\mathrm{K}$ and $1 / \mathrm{n}$ are Freundlich constants. Figure 5 show Freundlich adsorption isotherm for the adsorption of $\mathrm{Pb}^{2+}$ by oyster, snail and periwinkle shells. Values of Freundlich constant.are recorded in Table 2. 
From Table 2, it can seen that values of $\mathrm{n}$ for oyster, snail and periwinkle ranged from $2.0 \times 10^{4}-2.25 \times 10^{4}, 2.0 \times 10^{5}-3.33 \times 10^{5}$ and $1.25 \times 10^{4}-5.0 \times 10^{5}$, respectively. The number of adsorption sites that is available for adsorption is defined by $n$. This parameter alone does not determine the concentration of adsorbate that can be adsorbed at a given time. Other factors such as $\mathrm{pH}$, contact time, physicochemical composition and ionic radius of the adsorbate must be taken into consideration; hence values of $\mathrm{n}$ obtained from this work indicate that the number of adsorption site varied with time. Values of $\mathrm{K}$ calculated from Freundlich isotherms with respect to oyster and snail shells were constant within the contact time of 10 and 40 min but for periwinkle shell, $\mathrm{K}$ value tend to increase with time.

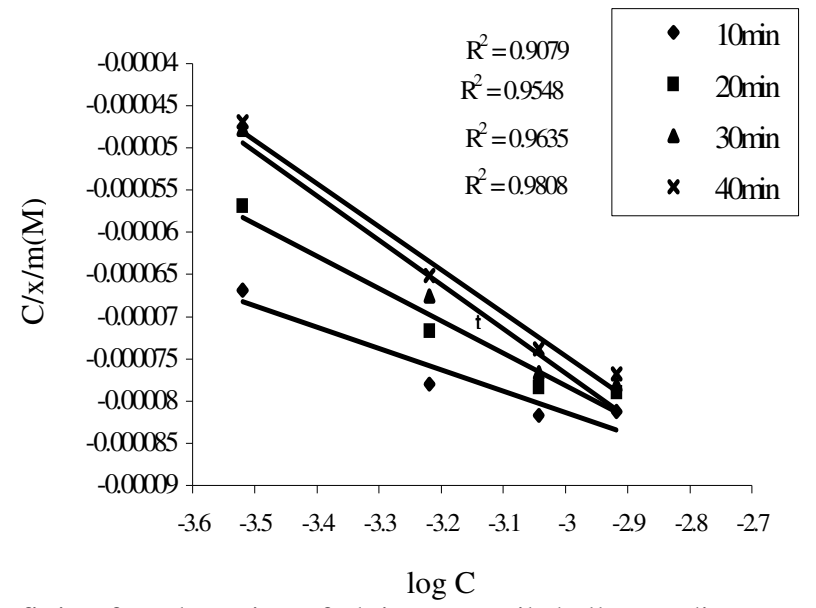

Figure 5. Curve fitting for adsorption of $\mathrm{Pb}$ ion on snail shell according to Freundlich isotherm.

Table 2. Values of Freundlich parameters for adsorption of $\mathrm{Pb}^{2+}$ on oyster, snail and periwinkle shells.

\begin{tabular}{ccccccc}
\hline \multirow{2}{*}{$\begin{array}{c}\text { Contact } \\
\text { time, min }\end{array}$} & \multicolumn{3}{c}{$\mathrm{n}$} & \multicolumn{3}{c}{ Equilibrium constant of adsorption, K } \\
\cline { 2 - 7 } & Oyster & Snail & Periwinkle & Oyster & Snail & Periwinkle \\
\hline 10 & $2.25 \times 10^{4}$ & $3.33 \times 10^{5}$ & $2.25 \times 10^{4}$ & 1.0005 & 1.0005 & 1.0012 \\
20 & $2.25 \times 10^{4}$ & $2.50 \times 10^{5}$ & $1.25 \times 10^{4}$ & 1.0005 & 1.0005 & 1.0013 \\
30 & $2.00 \times 10^{4}$ & $2.00 \times 10^{5}$ & $50.0 \times 10^{4}$ & 1.0005 & 1.0005 & 1.0021 \\
40 & $2.00 \times 10^{4}$ & $2.00 \times 10^{5}$ & - & 1.0005 & 1.0005 & - \\
\hline
\end{tabular}

The linear form of Temkin adsorption isotherm can be written as:

$$
\operatorname{Exp}(-2 \mathrm{ax} / \mathrm{m})=\mathrm{KC}
$$

Rearranging and taking logarithm on both sides of Equation 7, we get the following Eq.,

$$
\mathrm{X} / \mathrm{m}=-2.303 / 2 \alpha \log \mathrm{K}-2.303 / 2 \alpha \log \mathrm{C}
$$

Where, $\mathrm{K}$ is the equilibrium constant of adsorption and $\alpha$ is the interaction parameter. Temkin plot for the adsorption of $\mathrm{Pb}^{2+}$ by oyster shell is shown by Figure 6. Temkin adsorption isotherm was also applicable to adsorption of $\mathrm{Pb}^{2+}$ by snail and periwinkle shells (plots not shown). Values of Temkin constants are recorded in Table 3.

From Table 3 , it can seen that values of the interaction parameter $(\alpha)$ for oyster, snail and periwinkle ranged from $1.0 \times 10^{4}-9.0 \times 10^{5}, 1.0 \times 10^{4}-9.0 \times 10^{5}$ and $2.0 \times 10^{4}-9.0 \times$ $10^{5}$ respectively. Values of $\alpha$ were also found to vary with contact time indicating that the attractive behaviour of $\alpha$ depends on contact time. Values of $\mathrm{K}$ calculated from slopes of lines on Temkin plots ranged from $9.9885-9.9908,9.8855-9.9908$ and $9.9541-9.9724$ for 
oyster, snail and periwinkle shells, respectively. For periwinkle shell, values of $\mathrm{K}$ were found to decrease with contact time. For snail shell, $\mathrm{K}$ values were constant between 10 and $20 \mathrm{~min}$ of contact, but decreased after $20 \mathrm{~min}$ and increased marginally after $30 \mathrm{~min}$ of contact. However, for oyster, $\mathrm{K}$ was highest within $10 \mathrm{~min}$ of contact but reduced to a constant value between 20 and $40 \mathrm{~min}$ of contact. This indicates that the value of the equilibrium constant of adsorption varied with time.

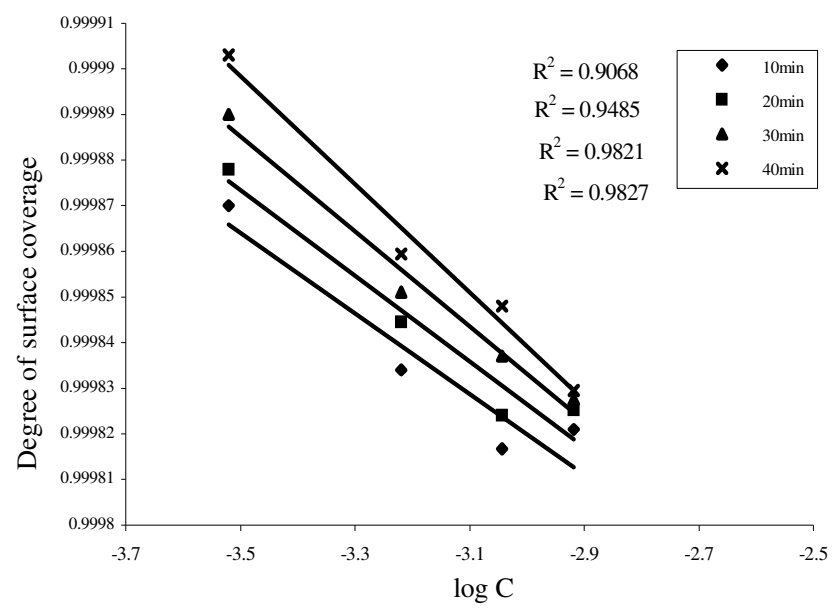

Figure 6. Curve fitting for adsorption of $\mathrm{Pb}$ ion on oyster shell according to Temkin isotherm.

Table 3. Values of Temkin parameters for adsorption of $\mathrm{Pb}^{2+}$ on oyster, snail and periwinkle shells.

\begin{tabular}{ccccccc}
\hline \multirow{2}{*}{$\begin{array}{c}\text { Contact } \\
\text { time, min }\end{array}$} & \multicolumn{3}{c}{ Interaction parameter, a } & \multicolumn{3}{c}{$\mathrm{K}$} \\
\cline { 2 - 7 } & Oyster & Snail & Periwinkle & Oyster & Snail & Periwinkle \\
\hline 10 & $6.0 \times 10^{5}$ & $9.0 \times 10^{5}$ & $9.0 \times 10^{5}$ & 9.9908 & 9.9908 & 9.9724 \\
20 & $9.0 \times 10^{5}$ & $9.0 \times 10^{5}$ & $2.0 \times 10^{4}$ & 9.9885 & 9.9908 & 9.9655 \\
30 & $1.0 \times 10^{4}$ & $1.0 \times 10^{4}$ & $4.0 \times 10^{4}$ & 9.9885 & 9.8855 & 9.9541 \\
40 & $1.0 \times 10^{4}$ & $1.0 \times 10^{4}$ & - & 9.9885 & 9.9885 & - \\
\hline
\end{tabular}

\section{Thermodynamic considerations}

The direction of any chemical reaction can be predicted by considering the free energy of the reaction ${ }^{20-22}$. The free energy of adsorption $\left(\Delta \mathrm{G}_{\mathrm{ads}}\right)$ of $\mathrm{Pb}^{2+}$ by oyster, snail and periwinkle shells is related to the binding constant of adsorption according ${ }^{8}$ to Eq. 9

$$
\Delta \mathrm{G}_{\mathrm{ads}}=-2.303 \mathrm{RT} \log \mathrm{K}
$$

Where, $\mathrm{R}$ is the universal gas constant and $\mathrm{T}$ is the temperature. Using values of $\mathrm{K}$ calculated from intercept of lines on Langmuir plots, values of $\Delta \mathrm{G}_{\mathrm{ads}}$ for adsorption of $\mathrm{Pb}^{2+}$ by oyster, snail and periwinkle shells were calculated. These values were recorded in Table 4. Calculated values of $\Delta \mathrm{G}_{\mathrm{ads}}$ ranged from $40.9512-44.6662 \mathrm{~kJ} / \mathrm{mol}, 41.9032$ - $43.6421 \mathrm{~kJ} / \mathrm{mol}$ and $41.2332-49.4512 \mathrm{~kJ} / \mathrm{mol}$ for oyster, snail and periwinkle shells, respectively. These values are negative indicating that adsorption of $\mathrm{Pb}^{2+}$ on the adsorbents were spontaneous. The values are also greater than $40.00 \mathrm{~kJ} / \mathrm{mol}$ indicating the mechanism of chemical adsorption is applicable to the adsorption of $\mathrm{Pb}^{2+}$ by the adsorbents. 
Table 4. Values of $\Delta \mathrm{G}_{\mathrm{ads}}$ for adsorption of $\mathrm{Pb}^{2+}$ by oyster, snail and periwinkle shells.

\begin{tabular}{cccc}
\hline Contact & \multicolumn{3}{c}{$-\Delta \mathrm{G}_{\mathrm{ads}}, \mathrm{kJ} / \mathrm{mol}$} \\
\cline { 2 - 4 } time, $\min$ & Oyster & Snail & Periwinkle \\
\hline 10 & 40.8512 & 41.9032 & 43.6722 \\
20 & 44.6662 & 41.9032 & 49.4512 \\
30 & 41.9032 & 41.9032 & 41.2331 \\
40 & 43.6421 & 43.6421 & - \\
\hline
\end{tabular}

\section{Distribution coefficient}

According to Eddy and Ukpong, ${ }^{23}$ the distribution of a solute between two phases is governed by a chemical law and the ratio of the concentration of the solute in one phase to the concentration of the solute in the second phase bears a constant value called distribution ratio or distribution coefficient (D). Ogunsuye et al. ${ }^{24}$ also stated that $\mathrm{D}$ is another measure of adsorption efficiency. It follows from the above that expression of the $\mathrm{D}$ can be written as Eq. 10.

$$
\mathrm{D}=\frac{\left[\mathrm{Pb}^{2+}\right]_{\mathrm{ads}}}{\left[\mathrm{Pb}^{2+}\right]_{\mathrm{aq}}}
$$

Where, $\left[\mathrm{Pb}^{2+}\right]_{\text {ads }}$ and $\left[\mathrm{Pb}^{2+}\right]_{\mathrm{aq}}$ are the concentrations of $\mathrm{Pb}^{2+}$ in the adsorbent and in the aqueous phase, respectively. Rearranging Eq. 10, we get the following equation.

$$
\left[\mathrm{Pb}^{2+}\right]_{\mathrm{ads}}=\mathrm{D} \times\left[\mathrm{Pb}^{2+}\right]_{\mathrm{aq}}
$$

The mathematical implication of Eq. 11 is that a plot of $\left[\mathrm{Pb}^{2+}\right]_{\mathrm{ads}}$ versus $\left[\mathrm{Pb}^{2+}\right]_{\mathrm{aq}}$ should give a straight line if the assumptions establishing Eq.10 are valid. Distribution plot with respect to adsorption of $\mathrm{Pb}^{2+}$ by snail shell is shown by Figure 7, (Distribution plots for oyster and periwinkle shells not shown). From slopes of lines on the plots, values of D were obtained and are recorded in Table 5. On the average, D values were higher for oyster and snail shells and least for periwinkle shell, thus confirming their relative adsorption efficiencies. Also values of D varied slightly with contact time indicating that time is of essence in determining the adsorption capacity of the adsorbents used.

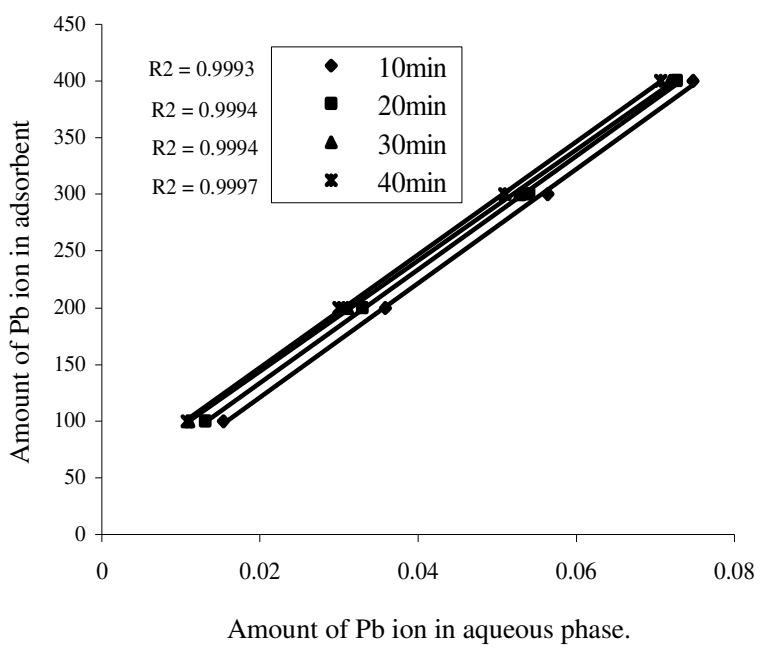

Figure 7. Distribution plot for adsorption of $\mathrm{Pb}$ ion by snail shell. 
Table 5. Distribution coefficient for adsorption of $\mathrm{Pb}^{2+}$ by oyster, snail and periwinkle shells.

\begin{tabular}{cccc}
\hline \multirow{2}{*}{$\begin{array}{c}\text { Contact } \\
\text { time, } \min \end{array}$} & \multicolumn{3}{c}{$\mathrm{D}$} \\
\cline { 2 - 4 } & Oyster & Snail & Periwinkle \\
\hline 10 & 5028.30 & 5045.40 & 1005.40 \\
20 & 4998.70 & 5122.90 & 1012.50 \\
30 & 4885.90 & 5176.40 & 1017.70 \\
40 & 4980.20 & 5163.10 & - \\
\hline
\end{tabular}

\section{Conclusion}

From the study, it has been found that shells of snail, oyster and periwinkle are good adsorbents for the removal of $\mathrm{Pb}^{2+}$ from aqueous solution. This confirms results obtained from previous studies. In addition, from the present study, the following conclusions are made:

(i) Based on their relative values of adsorption capacity, available surface area, distribution ratio and percentage sorption, adsorption efficiencies of these shells vary according to the trend: snail $>$ oyster $>$ periwinkle.

(ii) Adsorption capacities of snail, oyster and periwinkle shells are affected by contact time and by the initial concentration of $\mathrm{Pb}^{2+}$ in the solution.

(iii) Adsorption characteristics of snail, periwinkle and oyster shells are consistent with classical adsorption models of Temkin, Freundlich and Langmuir adsorption isotherms.

(iv) Within the limit of the studied concentrations, snail, oyster and periwinkle shells are confirmed to be good adsrbents for $\mathrm{Pb}^{2+}$ from aqueous solution.

\section{Acknowledgement}

The authors are grateful to Magdalene Job and Mr. I. Ating for technical assistance and to Mrs. Edikan Nnabuk Okon Eddy for her invaluable contribution.

\section{References}

1. Eddy $\mathrm{N} \mathrm{O}$ and Udoh C L, Fundamentals of Environmental Chemistry; Pattom Communication, Nigeria., 2006, Chapter 2-5.

2. Ansari R and Raofile F, E J Chem., 2006, 3, 35.

3. Ansari R and Raofile F, E J Chem., 2006, 3, 49.

4. Lori J A, Umoniyi I K and Ekanem E J, In Adsorption characteristics of mucin on Cahydroxyapalite, Akiniyi J A, Ed., Conference Proceedings, Chemical Society of Nigeria, Maidugri, Nigeria, 2005, pp 60-64.

5.. Gimba C E and Musa I A, In Adsorption of phenols and some toxic metals from textile effluents, Akiniyi J A, Ed., Conference Proceedings, Chemical Society of Nigeria, Maidugri, Nigeria, 2005, pp $55-59$.

6. Oviawe A P and Ademoroti C M A, In Adsorption of heavy metal ions from aqueous solution by some keratinous substances (cow horns). Akiniyi J A, Ed., Conference Proceeding, Chemical Society of Nigeria, Maidugri, Nigeria, 2005, pp $47-50$.

7. Rahman M A. Asadullah M, Hague M M, Motin N A, Siltan M B and Azad M A K, $J$ Surf Sci Technol., 2006, 22, 133.

8. Ufuah M O E, Ikhuaria E U and Okiemen F E, In Removal of select metal ions from aqueous solution with groundnut husk modifield with thioglycolic acid. Ahonkhai S I, Ed., Conference Proceeding, Chemical Society of Nigeria: Lagos, Nigeria, 2004, pp 235-236. 
9. Katsumata H, Kaneco S, Susuki T, Ohta K and Yobiko Y, Photo/Electrochem Photobiol, Environ Energy Fuel., 2004, 2, 165.

10. Blais J F, Shen S, Meunier N and Tyagi R D, Environ Technol., 2003, 24, 205.

11. Okuo J M, Global J Pure Appl Sci., 2006, 12, 355.

12. Okuo J M and Ozioko Anthony C, J Chem Soc Nigeria., 2001, 26, 60.

13. Badmus M A O, Audu, T O K and Anyata B U, Turk J Eng Environ Sci., 2007, 31, 251.

14. Tudor H, Gryte C and Harris C, Water Air Soil Pollut., 2006, 173, 209.

15. Ekop A S and Eddy N O, Afri J Environ Pollut Health., 2005, 4, 33.

16. Horsefall M and Spiff A I, Electronic J Biotech.,. 2004, 8, 162.

17. Horsfall M and Spiff A I, Afri, J Biotech., 2005, 4, 191.

18. Yurt A, Bereket G, Rivrak A, Balaban A and Erk B, J Appl Electrochem., 2005, 35, 1025.

19. Ofomaga A E, Okieimen F O and Omonmhenle S E, In Adsorption of $\mathrm{Cd}^{2+}$ and $\mathrm{Zn}^{2+}$ from aqueous solution by modifield koalanite, Ahonkhai S I, Ed., Conference Proceeding, Chemical Society of Nigeria: Lagos, Nigeria., 2004, pp 265 -272.

20. Sharma K K, Sharma L K, A textbook of physical chemistry, $4^{\text {th }}$ revised Ed., Vikas India, 2004, Chapter 7-8.

21. Khan R A, Tahir H, Uddin F and Hameed U, J Appl Sci Environ Manag., 2005, 9, 29.

22. Ogboinghale $\mathrm{F}$, Ugbesia $\mathrm{O} \mathrm{S}$, In Adsorption of $\mathrm{Pb}^{2+}$ and $\mathrm{Ni}^{2+}$ on orange peels. Akiniyi J A, Ed, Conference Proceeding, Chemical Society of Nigeria, Maidugri, Nigeria, 2005, pp 45- 46.

23. Eddy N O and Ukpong I J, J Appl Sci., 2006, 8, 60.

24. Ogunsuyi H O, Ipinmorpti K O, Amoda I A and Ajayi O, In Adsorption of $\mathrm{Cu}^{2+}$ aqueous solution using agricultural waste and oyster shell, Akiniyi J A, Ed, Conference Proceeding, Chemical Society of Nigeria, Maidugri, Nigeria, 2005, pp 43-46. 


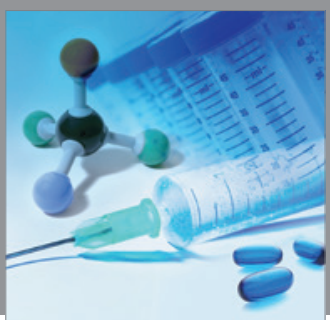

International Journal of

Medicinal Chemistry

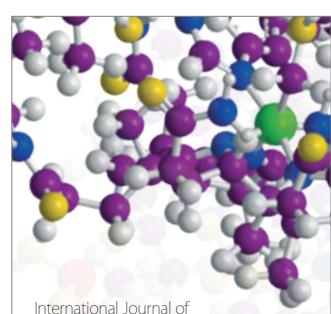

Carbohydrate Chemistry

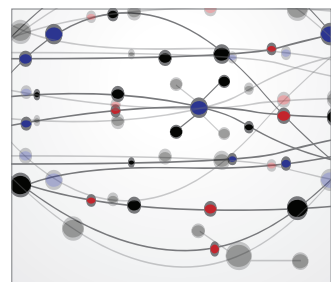

The Scientific World Journal
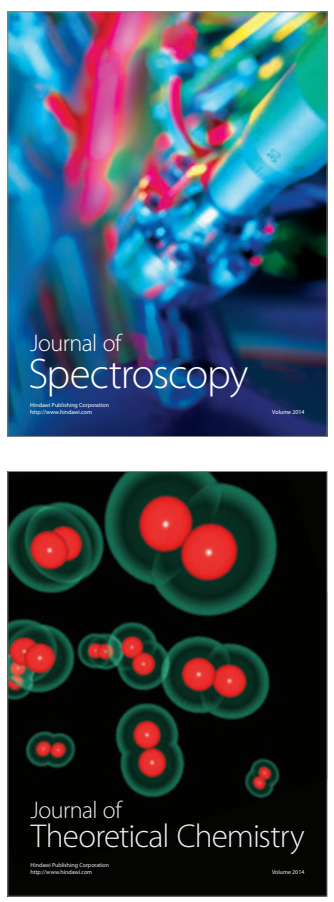
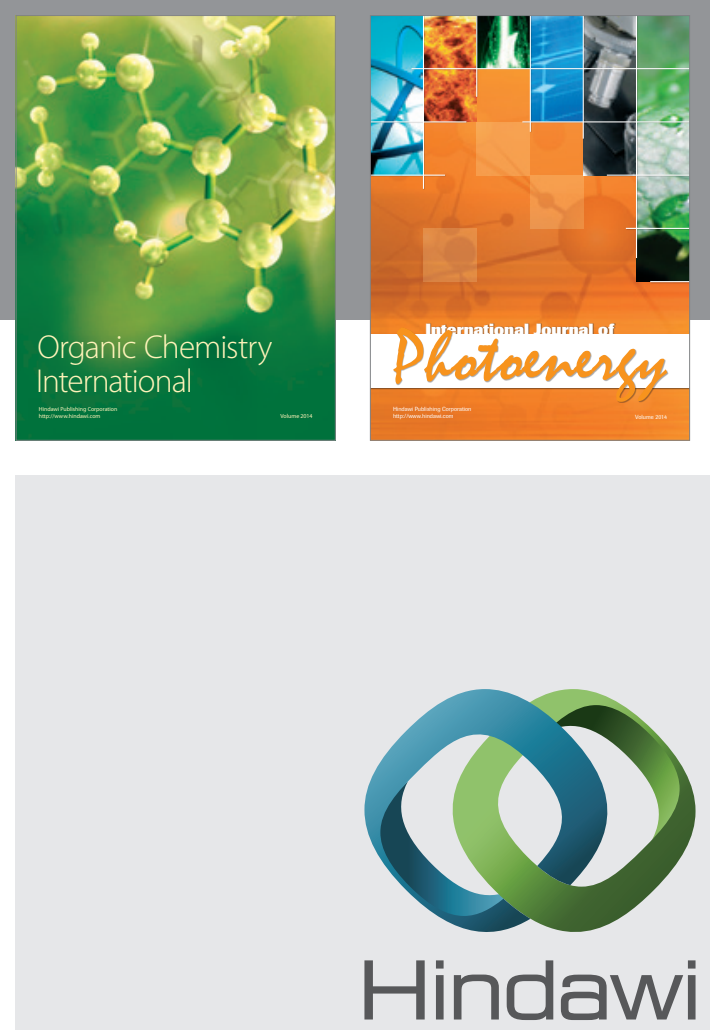

Submit your manuscripts at

http://www.hindawi.com
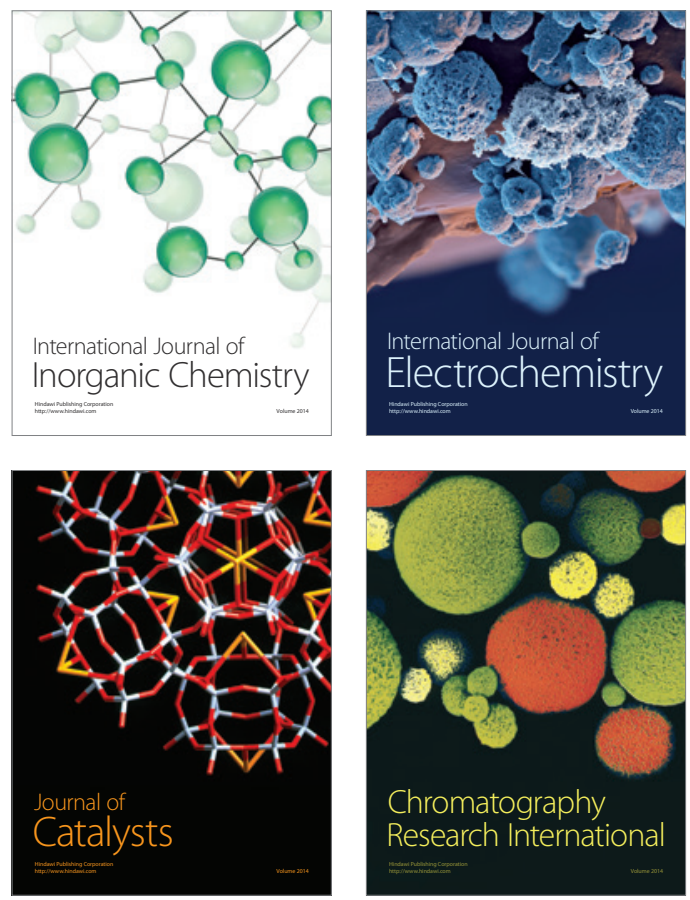
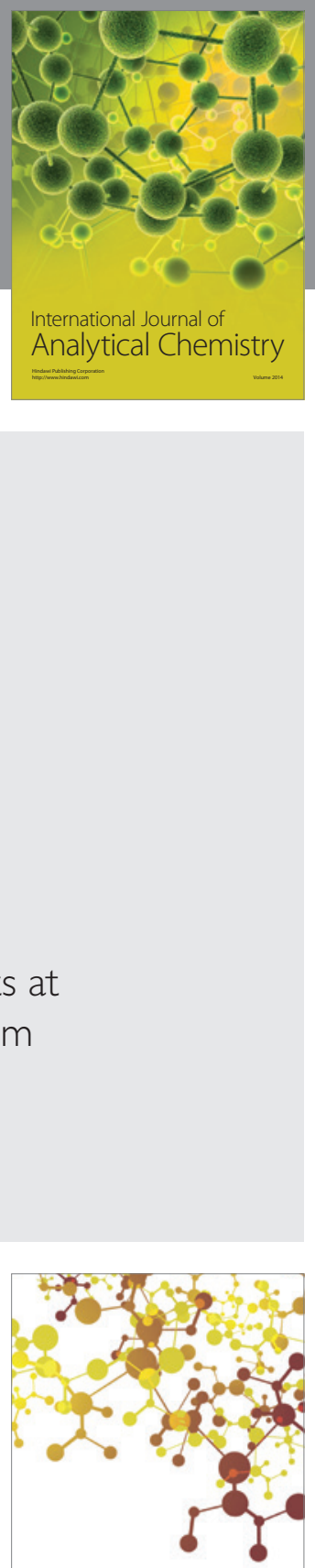

Journal of

Applied Chemistry
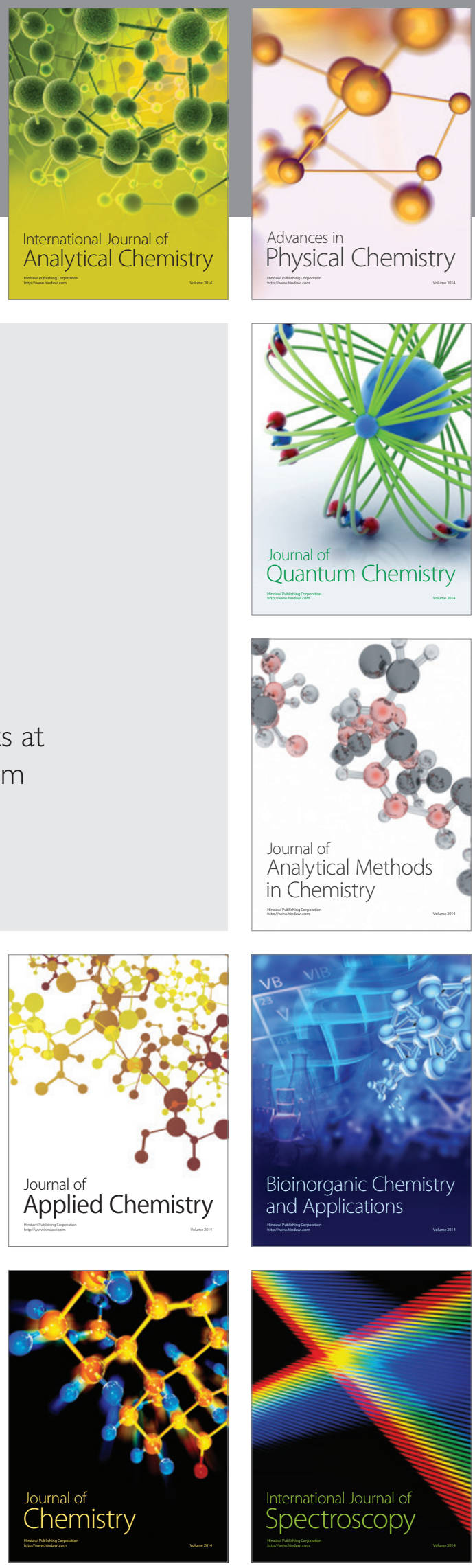